\title{
POSTFEMINIST TRENDS IN CONTEMPORARY YOUNG ADULT LITERATURE: THE REASSESSMENT OF THE VICTIM/ PERPETRATOR BINARY IN HELEN CROSS'S MY SUMMER OF LOVE
}

ABSTRACT. The paper discusses a postmillennial trend in contemporary culture characterized by an "exhaustion of originary victimary experience" and the questioning of postmodern "victimary thinking". It specifically focuses on postfeminists' criticism of "victim feminism" and their attempts to question the firm ethical opposition of the female victim and the male perpetrator that is central to victim feminism discourse. After a brief theoretical discussion of postfeminist approaches to the victimary paradigm that dominates second wave feminism, the paper proceeds to explain how this paradigm influenced both twentieth-century criticism and production of female Bildung narratives. Finally, it presents Helen Cross's coming-of-age novel My Summer of Love (2001) as an example of a new stage in the development of the genre marked by the author's attempt to reassess the female victim/ male perpetrator binary.

KEYWORDS: postfeminism; victim; perpetrator; bildungsroman.

Eric Gans in his web-published reflections in Chronicles of Love and Resentment associates the postmodern era with "victimary thinking"

1

ssnircova@gmail.com 
and proposes that the postmillennial age could become the new time of "non-victimary dialogue". Arising from the experience of Holocaust and Hiroshima, victimary thinking revolves around the conflict between the victim and the perpetrator that has acquired centrality in post-Holocaust, postcolonial and feminist discourses. Informed by the postmodern paradigm these discourses focus on the victim's perspective and stress the victim's non-negotiable ethical opposition with the perpetrator. Although Gans (2001) himself believes that the development of an effective non-victimary dialogue is threatened by the continuous, "chronic" presence of victimary resentment in post-2000 culture, some cases of the turn-of-the-millennial and contemporary art suggest new approaches to the victim/ perpetrator binary.

Raoul Eshelman (2006), for example, identifies certain "exhaustion of originary victimary experience" in post-Holocaust literature that "has given rise to works whose means of arguing are ultimately more aesthetic than didactic or documentary". He notices that some "books and movies are now beginning to focus on perpetrators, the ethical choices involved in their actions and, above all, on the possibility of atonement and reconciliation that these choices imply". The most prominent and the most discussed example of this new trend is Bernhard Schlink's Der Vorleser [The Reader] (1997) that, according to Eshelman, "breaks with postmodernist norms by framing or artificially uniting victims and a perpetrator in closed, ritualistic scenes". Eshelman identifies a similar trend in the postcolonial writing that turns away from the sole focus on the subaltern victim in conflict with the hegemonic centre. Taking as an example the works of postcolonial literature by Arundhati Roy, The God of Small Things (1997) and The Cost of Living (1999), he maintains that Roy offers perspectives "radically different from those current in postmodernism and postcolonial studies". She not only portrays India and the West, capitalism and Marxism as "equivalent in terms of arrogance, despotic hubris and destructiveness", but she also apparently replaces the victimary stance with the belief that love and beauty are "the basic givens of human interaction".

In this paper I discuss a similar trend in contemporary postfeminist thinking in which criticism of "victim feminism" is combined with the attempts to question the firm ethical opposition of the victim and the perpetrator. After a brief theoretical discussion of postfeminist approaches to the victimary paradigm that informs second wave feminism, I proceed to explain how this paradigm 
influenced both twentieth-century criticism and production of female Bildung narratives. Finally I present Helen Cross's comingof-age novel My Summer of Love (2001) as an example of a new stage in the development of the genre marked by the author's attempt to reassess the victim/perpetrator binary.

The best known and most visible critiques of "victim feminism" have been produced by popular press feminist writers: e.g. Katie Roiphe in The Morning after: Sex, Fear and Feminism (1993), Naomi Wolf in Fire with Fire (1994); Rene Denfeld in The New Victorians (1995) and Natasha Walter in The New Feminism (1998). These critics relate the rising unpopularity of feminism to the changes in the feminist movement that have become associated with the radical marginthe voices that present feminism as "puritanical, man-hating, and obsessed with defining women as "victims"' (Wolf 1993, p. xvii). Naomi Wolf (1993) suggests a way out from the crisis of feminist ideology in its move away from the "victim feminism" that, in her opinion, dominates contemporary academic discourse to the "power feminism" associated with the origins of the movement.

Wolf's characterization of victim feminism includes such features as the identification of women with powerlessness, the idealization of women's childbearing capacity as a "proof" that women are better than men, the belief that women are naturally non-competitive, cooperative and peace-loving, the projection of aggression, competitiveness and violence on to "men" or "patriarchy", and the perception of women as pure and perfect (Wolf 1993, pp. 148-149). In contrast to this, power feminism "acknowledges that aggression, competitiveness, the wish for autonomy and separation, even danger of selfish and violent behaviour, are as much a part of female identity as is nurturant behaviour. It understands that women, like men, must harness these impulses and sees women as moral adults" (Wolf 1993, p. 150). Most importantly power feminism stresses female agency and freedom of choice. Rene Denfeld $(1995$, p. 12) agrees with Wolf that it is the radical feminist voice that dominates the organized, ideological forms of feminism and claims that its discourse of "victim mythology, a set of beliefs that promote women as the helpless victims of masculine oppression" alienates the organized feminist movement from the women's cultural movement. This cultural movement, Denfeld maintains, gives evidence of women's ability to take independent, active positions in their search for equality with men. 
Popular postfeminists' arguments, such as the ones outlined above, have in general provoked negative reactions of academic criticism. For example, Sarah Gamble (1998, p. 39) accuses them of "adopt[ing] a dangerously simplistic attitude towards feminism". Rebecca Stringer (2014, p. 18) analyses popular postfeminists" "misreadings" of second wave feminism as an ideology rooted in victimology and points out that they "contributed powerfully to the creation of a new and distinctly neoliberal version of feminism that has become pervasive". However, Stringer also notices significant overlaps between neoliberal discourse, popular postfeminism and academic postmodern feminism. Postmodern feminism or "academic postfeminism", as some call it (Genz and Brabon 2009), is defined by its intersections with complex postmodernist, poststructuralist and postcolonial theories that are often used to critically explore the second wave feminists' notion of woman as a passive victim of patriarchy. Stringer (2014) suggests that in this way postmodern feminist scholars may participate in neoliberal feminism (postfeminism) that aligns young women with agency, power, choice and personal responsibility, and thus encourages them to turn away from the fight against structural oppression. Angela McRobbie (2004), on the other hand, draws attention to the fact that the free choice that postfeminism celebrates may include the willing return to the traditional female roles, such as the housewife or the sexual object. She stresses that these traditional choices appear to be promoted by the postfeminist media culture that exploits the female anxieties related to the biological clock pressures and the "stigma of remaining single" (McRobbie 2004, p. 11).

Although one can agree with Stringer's claim that the postfeminist interpretations of second wave feminism as a victim politics are reductive, the focus on women as victims of patriarchy undoubtedly presents a central line of second wave feminists' arguments in many areas of their academic explorations. Feminist scholarship in the field of the Bildungsroman is an illustrative case since the victimary perspective lies at the heart of its exploration of the genre. Feminist Bildungsroman scholars (Abel, Hirsch and Langland 1983, Labovitz 1986, Pratt 1981) have established the classic female Bildungsroman as a specific version of the genre primarily through their definition of the Bildungsroman heroine as a literary character whose ("inferior") gender importantly conditions the course and (in)completion of her personal development. The restrictions that the eighteenthand nineteenth-century societies imposed on the traditional hero- 
ines in the form of the patriarchal norm have been offered by critics as the main reason for the female protagonist's less direct and more conflicted process of maturation. In their studies of both classic and more modern examples of the female Bildungsroman, such as Charlotte Brontë's Jane Eyre and Villete, Louisa MayAlcott's Little Women, Kate Chopin's The Awakening, Virginia Woolf's Mrs. Dalloway, Jean Rhys's White Sargasso Sea and many others these authors offer a criticism of male-centred approaches to the genre. They point out that many of the constitutive elements of the protagonist's development provided by male critics of the Bildungsroman, such as formal education, independent life in the city, two love affairs and an active interaction with society, traditionally did not belong among the social options available to women. The inequality that female protagonists experience in terms of social options, such as access to the public space of formal learning and employment, or in terms of the development of independent agency (hindered by marital and maternal roles) is seen as a crucial factor that prevents the heroines from achieving full maturity. Critics maintain that female Bildung in these novels tends to be either incomplete or interrupted by the premature death of the heroine, who cannot cope with the constraints imposed on her by patriarchal society. More radical voices deny the very possibility of any positive development of Bildunsroman heroine and instead they speak of her "growing down," "a choice between auxiliary or secondary personhood, sacrificial victimization, madness and death" (Pratt 1981, p. 36). Even those who disagree with the radical claim about the lack of any positive female development in eighteenth- and nineteenth-century texts believe that the heroine's autonomy is limited. Lorna Ellis (1999) claims that the classic Bildung heroine "successful" development depends on her ability to learn "to see herself as others see her, learning how to experience herself as the object of the other people's gaze" (p. 30). This helps her "create a manipulative form of control" (p. 33) over her husband (a form of empowerment) but her overall development remains determined by women's greater association with the domestic sphere, which has left them, for centuries, "legally and socially powerless as individuals" (p. 46).

The perception of woman as a victim of patriarchy also informs academic discussions about the twentieth-century feminist Bildungsroman that appeared in the context of second wave feminism and reveal "a critical awareness of women's subordinate position and of gender as a problematic category" (Felski 1989, p. 14). As a 
specific genre it represents "a new narrative model, in which the otherness of the female protagonist does not result in her subsequent death or defeat but provides the impetus for a sustained refusal of patriarchal values. Rather than offering a negative critique of society by depicting the destruction of a female victim, the contemporary writer describes a form of opposition through the resistance and survival of the heroine" (p. 130). Due to its rejection of marriage as a significant endpoint of the protagonist's development, the feminist Bildungsroman can be seen as a specific transformation of the nineteenth-century female novel of development which exposes the insufficiency of its traditional plot (p. 128). The genre focuses on the heroines' "symbolic act of separation" (p. 126) from the traditional social roles of wife, housewife and mother. Separating themselves from the domestic sphere, the heroines negotiate the opportunities available to them in the twentieth-century public space of education, work and politics in a similar way to how the young middle-class heroes of the classic male Bildungsroman explore the possibilities offered to them by modern society in the eighteenth and nineteenth centuries.

An important point of difference, however, remains, as Ester Kleinbord Labovitz (1986, p. 251) states, that "the theme of equality between sexes is one sharply stressed in the female Bildungsroman, alone". While male heroes leave their homes due to conflicts with their fathers or father figures, in search of independent life in the city, the heroines of feminist narratives leave their homes due to the strong sense of alienation caused by their confinement in the domestic sphere, the drudgery of housework and the constraints of marital and maternal roles (Felski, 1989, p. 130). An important precondition for the heroine's successful personal development and avoidance of becoming a victim of patriarchy is her disengagement from the world of heterosexual romance. Labovitz (1986, p. 248) maintains that the "quest for an authentic self" is often "carried out in loneliness, alone, with other women, safe from the eyes of the male world", and Felski (1989, p. 138) adds that presenting heterosexual marriage as "the very antithesis" of female Bildung, the feminist Bildungsroman invariably includes a female friend or lover that "plays a symbolically important role in the protagonist's development". The ideal of sisterhood that these novels present is sustained by the assumption that female community can create "personal bonds which may serve to challenge the instrumental rationality of social relations in a male-defined public sphere" (Felski 
1989, p. 140). The belief in the common, particular nature of female experience and the necessary antagonism between the values of female and male communities are defining elements of this feminist genre, which is, according to Felski (1989, p. 140), based on an essentially optimistic vision of history as "progressive emancipation".

A brief look on the history of the female coming-of-age novel reveals that images of girls as victims of patriarchal power form an integral part of the genre. The coming-of-age novel emerged as a specific twentieth-century literary form that does not concern itself with significant stages of development from childhood to adulthood (the protagonist's coming of age) but focuses on the coming-of-age process during which the protagonist acquires some crucial insights into adulthood. Placing at the centre the process of personal development in specific socio-cultural and historical conditions the coming-of-age novel is necessarily related to the tradition of the Bildungsroman, but it also includes enough significant differences that justify its treatment as a separate genre. One of the central defining element of the genre, as many agree (White 1985, Saxton 1998, Rishoi 2003), is the adolescent age of the protagonist"by definition a time of rebellion and resistance" (Rishoi 2003, p. 9)-that provides women authors with a possibility to explore "contradictory desires and discourses" and question the power of dominant ideologies to construct their lives". The scope of the story time covered in the coming-of-age novel tends to be restricted to short periods of a few months or a couple of years during which the protagonists experience some turning points in their journey to adulthood. Finally, the Bildungsroman has been seen by critics (Bakhtin 1986, Moretti 2000) as the main literary form of modernity with its specific understanding of personal identity as a unified rational self, and of youth as an important transitory period during which the construction of the self must be completed to signify the individual's ability to participate in social progress. The coming-ofage novel, on the other hand, can be as an offspring of the postmodernity with its focus on the crisis of identity and the celebration of the "eternal" youth. In the era when the inability or unwillingness to mature and accept responsibilities of adult life has become "normality", coming-of-age narratives that often focus on individuals locked in adolescence and alienated from the social and cultural structures of the adult world represent one of the most popular forms of young adult literature. 
As scholarly studies of female coming-of-age novels suggest, the alienation of the girl protagonists is crucially determined by their gender that generates specific aspects of their conflict with society. Both major books on the representations of girlhood in twentiethcentury (mostly) Northern American literature (White 1985, Saxton 1998) argue that the adolescent girl tends to be portrayed as a victim of patriarchy. Barbara A. White's (1985) study of the girl protagonists in novels by American female authors written between 1920 and 1982 indicates that despite the rising influence of feminist thought on American society, the images of girlhood remained rather bleak during that period. Most frequently, the examined novels of female adolescence "include scenes of male sexual harassment or violence" (p. 175), which corresponds with White's point that "female adolescence is a social state characterized by weakness" (p. 189). White compares the girl protagonist with the adolescent hero who may choose to be a "rebel-victim" (p. 191). The hero makes an existential choice to rebel "against the 'immitigable rule of reality', that is, the human condition", while the girl heroine, who is a real victim, "rebels not because her human body is doomed, by immitigable rule of reality, to imperfection and death, but because her female body, by mitigable rule of society, dooms her to subservience" (p. 191). The female body as a site of struggle and a reason for the girl heroine's victimization also appears in the coming-of-age narratives explored in a collection of essays edited by Ruth O. Saxton (1998). However, some of the novels examined do suggest a change presenting the adolescent heroine who rejects her passive victim role and fights back. Renee R. Curry (1998) argues that this new type of heroine defies not only patriarchal but also feminist assumptions about girlhood: "This homology between girls and innocence deems young females to be blameless, faultless, virtuous, spotless, pure of heart, irreproachable, inculpable, chaste, guiltless, guileless, harmless, simple, naïve, unsophisticated, artless, unknowledgeable, and free from responsibility" (p. 96). The rejection of the equation of the girl with innocence that Curry (1998) identifies in such novels as Jamaica Kincaid's Annie John (1983), Carolyn Chute's The Beans of Egypt, Maine (1985) and Dorothy Allison's Bastard Out of Carolina (1992) heralds the new perspectives on girlhood that dominate postfeminist popular culture.

In the following pages I discuss a British coming-of-age novel that also problematizes association of girlhood with innocence and reassesses the female victim/male perpetrator binary. My Summer of 
Love (2001) was written by a young author in her early thirties and made an important contribution to the field of young adult literature, winning Betty Trask Prize and Awards in 2002. The novel focuses on a summer story of two teenage girls whose crimes result in the death of their male victims. Helen Cross offers a critique of the traditional equation of the girl with weakness and passivity but also stresses the girls' perpetrator/victim double role. Raising questions about society's and girls' personal share of responsibility for their crimes, she offers a postfeminist treatment of women's agency, power and choice.

My Summer of Love is set in a 1984 small Yorkshire town and through a retrospective narrative focuses on a few weeks of an intense intimate relationship between Mona, daughter of a local pub's landlord, and Tamsin, an upper-middle class girl from a nearby mansion. Mona's and Tamsin's characters support the power feminists' point that impulses towards aggressive, selfish and violent behaviour are integral to female identity and thus question the more traditional feminist images of a girl as an innocent victim of patriarchal evils. As a protagonist and the narrator of her own coming-ofage story, Mona offers a perfect example of the dissociation of girlhood and innocence that Renee R. Curry (1998) notices in her discussion of American representations of the genre. Due to her mother's death, her older sister's recent marriage and her step mother's escape with another man, Mona is left without any female mentor who would guide her through her adolescent problems and misconducts. At the beginning of the novel she appears to exist on the threshold of middle-class respectability and the less appealing side of society, a position expressed by the symbolic placement of her father's pub "Adam and Eve" on the borderline between two worlds:

Viewed from this side our street was decent; messy glass-porched semis, a short terrace, caravans, bikes, kids, a post-box on a crescent of yellowing grass. Round the back was certainly the sort of place you'd dump someone you'd killed: shattered windows, splintered wood, dead factories, abandoned warehouses... (p. 4)

Associating respectability with boredom (she sees her delinquent sister's turn into a respectable wife as ridiculous), Mona feels attracted towards the world of crime that she, in her teenage confusion, romanticizes: "So badly did I want to commit crimes I was fascinated by the police before I'd even done anything... I knew people who'd been on probation and romantically I imagined it as a state-owned dating agency to put teenage girls in touch with blond, 
hunky policemen" (p. 3). In consequence, she goes through a phase of delinquent rebelliousness which includes heavy drinking, fruit machines gambling addiction and the criminal activities (shoplifting and burglary) that she gets away with, as they are overshadowed by the community's search for the body of a missing girl.

Julie Flowerdew, the suspected victim of a sexual predator, is the novel's central symbol of female weakness and victimhood, set in contrast with Mona's and Tamsin's more ambiguous roles. The representation of adolescent girlhood as the most vulnerable stage of female development within patriarchal power structures pervades the narrative and opens the possibility to see Mona, to a certain extent, as the girl heroine who rejects the passive victim role and fights back. A shortened version of Hamlet's famous statement to Ophelia, "Get thee to a nunn'ry, why woulds't thou be a breeder of sinners?" appears, in several variations, as the narrative's refrain that reflects Mona's awareness of her vulnerable position in the world of men. The images of men that appear in the novel are far from appealing. They are adulterers and poor fathers (Mona's and Tamsin's dads), underage girls' abusers (middle-aged Phil who takes Mona's pornographic photographs and has sex with her), religious fanatics (Mona's brother-in-law), and sexists with crude remarks about women (the regulars in the pub), monsters (Julie's anonymous kidnapper and murderer) and lazy good-for-nothings (Mona's obese stepbrother).

Perceiving men as being either "dangerous predators" or "lardy loser" (p. 52), Mona welcomes an opportunity to escape from the pressures of the male world into the female friendship with Tam$\sin$. The several days of their secret stay in Tamsin's parents' empty house gives them an opportunity to explore their lesbian relationship and construct female autonomy in the way that echoes the feminist Bildugsroman heroine's search for the authentic selfthrough her separation from heterosexual romance and "safe from the eyes of the male world" (Labovitz, 1986, p. 248). Just like in the feminist Bildungsroman, the female friend and lover plays an important role in the heroine's development: Tamsin crucially influences Mona's personality and pushes her towards the tragic solution of her adolescent conflict with men. Instead of acquiring an authentic self, Mona falls more and more under the spell of the disturbed girl that feeds her on untrue stories about her sister's death of self-starvation, deepens her problems with heavy drinking and anorexia and drags her into a folie à deux state that culminates in murder. 
The novel clearly draws on the feminist idea of female sisterhood, but presents its less appealing sides, jealousy, distrust, deceit, and the dark aspects of the girl power that it can produce. Mona's and Tamsin's escape into their private and intense friendship is motivated, at least partly, by their feelings of betrayal and abandoned by their (step) mothers and sisters who are not there to help them through the process of growing up. Their violent acts that include verbal abuse of an elderly woman whose old-age ugliness fuels their cruelty and an attack at Tamsin's father's mistress indicate that their conflict with women is as intense as the one with men. Despite Mona's idealization of their lesbian romance, distrust, deceit and manipulation also lie at the core of her relationship with Tamsin, the beloved and feared object of her desire. While Julie Flowerdew is a symbol of female innocence destroyed by male monstrosity, Tamsin, the initiator of the violent crimes, is the "crazy girl" that Mona mistakes for her saviour (p. 71). She is the "mad woman"-the classic figure of female raging and revenge-that occupies the symbolic attic of her father's patriarchal house.

Caught between the two symbols, Mona is a girl in a borderline position. She is the potential victim of the unknown murderer, the actual victim of the older man's sexual abuse, and even the victim of Tamsin's manipulation and deceitfulness. But she is also the perpetrator of the crimes whose pointless cruelty makes her question the girl power and public recognition she desires:

Somewhere, I feared our new confidence was based on nothing but the lazy flame of extreme unkindness. And I badly wanted it to evolve into more than this; I wanted it to be clever, witty, admirable, for us to be like people in a book or on TV. I wanted people to recognize our power, celebrate it and think we are a cool, finger-snapping success. I hated the idea of just being averagely mean and bitchy. (p. 153)

Mona's adolescent desire for a masculine role and recognition in the public space is frustrated by her experience of the world in which women are reduced to the roles of wives, mothers and mistresses. The frustration makes her follow Tamsin, literally and symbolically, into the attic room of the patriarchal house in which their despair and boredom grow to culminate in the final acts of "madness": the blackmailing of Phil, the false implication of Phil in Julie's murder that leads to his suicide and the violent drowning of Mona's obese stepbrother PorkChop. Although Mona's retrospective narrative presents the crimes as undoubtedly cruel and condemnable, from the reader's perspective they are submerged in ambiguity that 
problematizes the ethical opposition between the victim and the perpetrator.

While Phil's death appears as an unintended consequence of Mona's attempt to fight back and punish Phil's abusive behaviour, her participation in the murder of friendly and supportive PorkChop is a "mad woman in the attic" act. The passage in which two weak anorectic girls' fight with and finally overpower the huge fat body of the young man acquires a symbolic meaning. The girls' "madness" (“... now we were pushing [life] out [of him]. It was fun"), p. 244) mingles with their fear of predatory maleness and the anger at their lack of power in the world dominated by men. By the scapegoating of an innocent member of the male community, Mona and Tamsin experience intense, though, only momentary empowerment and reacquire the almost lost feeling of "true" sisterhood: ...by doing something together our love was complete again...I was so glad the rage between Tam and me was over. Anger between women was too hot and frightening, too terrible to be believed. I hung onto her arm to steady mesen as I pushed and pushed him under with the flat palm of me thin little hand" (pp. 242, 244).

Passages like these illustrate that Helen Cross's novel offers a bleak version of the feminist narratives of development that, according to Rita Felski (1989, p. 130) replace "a negative critique of society by depicting the destruction of a female victim" by "a form of opposition through the resistance and survival of the heroine." While the novel constantly encourages the reader to sympathise with the confused girl protagonists and perceive them as the victims of parental negligence and patriarchal abuse, it equally strongly undermines association of girlhood with innocent victimhood. In addition, the non-idealisation of lesbian romance and the focus on the dark sides of sisterhood take Cross's novel away from the feminist narratives in which utopian visions of female community play an important role in women's coming of age. Mona and Tamsin's story seems to question the belief that women can easily forge personal bonds that could automatically generate a positive challenge to patriarchal power structures. The protagonists' interactions with the public sphere through their criminal acts represent the least productive form of opposition to the oppressive society turning them into the perpetrators whose monstrosity equals the one of their male counterparts. 
REFERENCES Abel, E., Hirsch, M. \& Langland, E. (Eds.) (1983). Voyage In: Fictions of Female Development. Hanover and London: UP of New England.

Bakhtin, M. M. (1986). The Bildungsroman and Its Significance in the History of Realism (Toward a Historical Typology of the Novel. In C. Emerson and M. Holquist (Eds.), Speech Genres and Other Late Essays (V. W. McGee, trans.) (pp. 10-59). Austin: University of Texas.

Curry, R. C. (1998). 'I Ain't No Friggin' Little Wimp': The Girl 'I’ Narrator in Contemporary Fiction. In R. O. Saxton (Ed.), The Girl: Construction of the Girl in Contemporary Fiction by Women (pp. 95-105). New York: St. Martin's Press.

Cross, H. (2001). My Summer of Love. London: Bloomsburry.

Denfeld, R. (1995). The New Victorians: A Young Woman's Challenge to the Old Feminist Order. New York: Warner Books.

Ellis, L. (1999). Appearing to Diminish: Female Development and the British Bildungsroman, 1750-1850. London: Associated UP.

Eshelman, R. (2006). After Postmodernism: Performatism in Literature. Anthropoetics XI, no. 2 Fall 2005/Winter 2006, Last updated: October 15, 2016, http://anthropoetics.ucla.edu/ap1102/perform05/\#n28. Accesses 15 July 2018.

Felski, R. (1989). Beyond Feminist Aesthetics. Feminist Literature and Social Change. Cambridge, Massachusetts: Harvard University Press.

Gamble, S. (1998). Postfeminism. In The Routledge Companion to Feminism and Postfeminism, Sarah Gamble, ed., 36-45, London: Routledge.

Gans, E. (2001). Victimary Thinking Forever? http://anthropoetics.ucla.edu/ views/vw230/ № 230: Saturday, March 31 ${ }^{\text {st }}$. Accessed 15 July 2018.

Genz, S. \& Brabon, B. A. (2009). Postfeminism. Cultural Texts and Theories. Edinburgh University Press: Edinburgh.

Labovitz, E. K. (1986). The Myth of the Heroine: The Female Bildungsroman in the Twentieth Century, Dorothy Richardson, Simone de Beauvoir, Doris Lessing, Christa Wolf. New York: Peter Lang.

McRobbie, A. (2004). Notes on Postfeminism and Popular Culture: Bridget Jones and the New Gender Regime. In A. Harris (Ed.), All about the Girl. Culture, Power and Identity (pp. 3-14). New York, London: Routledge.

Moretti, F. (2000). The Way of the World: The Bildungsroman in European Culture. (A. Sbragia, trans.). London, New York: Verso.

Pratt, A. (1981). Archetypal Patterns in Women's Fiction. Bloomington: Indiana University Press.

Rishoi, C. (2003). From Girl to Woman: American Women Coming-of-Age Narratives. Albany: State University of New York Press.

Roiphe, K. (1994). The Morning After: Sex, Fear, and Feminism. Little, Brown and Company. 
Saxton, R. O. (Ed.) (1998). The Girl: Construction of the Girl in Contemporary Fiction by Women. New York: St. Martin's Press.

Stringer, R. (2014). Knowing Victims. Feminism, Agency and Victim Politics in Neoliberal Times. London and New York: Routledge.

Walter, N. (1999). The New Feminism. London: Virago.

White, B. A. (1985). Growing up Female: Adolescent Girlhood in American Fiction. Westport and London: Greenwood Press.

Wolf, N. (1994). Fire with Fire: The New Female Power and How It Will Change the $21^{s t}$ Century. London: Vintage.

СОНА ШНИРЦОВА

УНИВЕРЗИТЕТ ПАВОЛ ЈОСЕФ ШАФАРИК

ФИЛОЗОФСКИ ФАКУЛТЕТ

ОДСЕК ЗА БРИТАНСКЕ И АМЕРИЧКЕ СТУДИЈЕ

РЕЗИМЕ

ПОСТФЕМИНИСТИЧКИ ТРЕНДОВИ У САВРЕМЕНОЈ КЮИЖЕВНОСТИ ЗА

МЛАДЕ: ПРЕИСПИТИВАҢЕ БИНАРНЕ ОПОЗИЦИЈЕ ЖРТВА/ЗЛОЧИНАЦ У РОМАНУ ХЕЛЕН КРОС ЛЕТО ЉУБАВИ

Рад се заснива на проучавању најновијих трендова савремене културе коју карактерише „презасићеност оригиналним искуствима жртве“, као и на преиспитивању постмодерног приступа „начину на који жртва размишља“. Посебна пажња посвећује се постфеминистичкој критици „феминизма жртве“ која има за циљ да истражи етички супротстављене односе женске жртве и мушког починитеља. Након кратког теоријског осврта на постфеминистичке приступе парадигми жртве која је доминантна у другом таласу феминизма, у раду се појашњава како је ова парадигма утицала како на књижевну критику XX века тако и на продукцију женских билдунг наратива. Коначно, билдунгсроман Лет̄о љубави Хелен Крос (2001) узима се као пример нове фазе у развоју жанра при чему ауторка романа настоји да преиспита бинарну опозицију жртва/починилац.

КљУчнЕ РЕчи: постфеминизам; жртва; починилац; билдунгсроман.

Овај чланак је објављен и дистрибуира се под лиценцом Creative Commons Ауторство-Некомерцијално Међународна 4.0 (СC BY-NC 4.0 |

https://creativecommons.org/licenses/by-nc/4.0/).

This paper is published and distributed under the terms and conditions of the Creative Commons Attribution-NonCommercial International 4.0 licence (CC BY-NC 4.0 | https://creativecommons.org/licenses/by-nc/4.0/). 